\title{
FAIR VALUE IN THE VALUATION OF DAMAGE TO PROPERTY CAUSED BY INDIRECT NUISANCE CREATED BY COMPANIES
}

\author{
Jan Konowalczuk, PhD. \\ Department of Investments and Property \\ University of Economics in Katowice \\ e-mail: jan.konowalczuk@ue.katowice.pl
}

\begin{abstract}
The article presents the theoretical concept and economic justification for using fair value as a basis for determining the value of damage caused by indirect nuisance created by companies and as a basis for appraising real estate for that purpose. The conditions and possibilities of applying fair value in Poland are assessed against the background of selected economic concepts of market fairness and market efficiency. The author focuses his considerations on the purposes of valuating the property of households in a conflict situation involving setting the amounts of compensation for external impacts of companies' activities. The theoretical considerations are put in practical context by the assessment of the possibility to use fair value in Poland for appraising property located in the limited use areas of airports (LUA of airports) when estimating damage resulting from the loss of value due to the legalization of noise nuisance.
\end{abstract}

Key words: fair value, indirect nuisance, external impacts, market efficiency and market fairness, noise in LUA of airports.

JEL Classification: $R 30, D 03, D 70$.

Citation: Konowalczuk J., 2018, Fair Value in the Valuation of Damage to Property Caused by Indirect Nuisance Created By Companies, Real Estate Management and Valuation, vol. 26, no. 3, pp. 60-70.

DOI: $10.2478 /$ remav-2018-0025

\section{Introduction}

Economic development is accompanied by conflicts related to the use of physically and economically limited land resources and other economic assets. Private ownership fosters market development, as it enables the beneficial exchange of rare/finite resources. In comparison with other economic goods, due to its permanent character, real property is particularly exposed to neighbor disputes. These usually occur when there is disagreement as to how property should be used or when the intensity of its use varies. In the current post-industrial period, the intensification of urbanization processes results in the escalation of conflicts due to external impacts caused by various types of nuisance, such as noise, foul smells, smoke, dust, water, vibrations, tremors, obstruction of sunlight, etc. These are produced by enterprises whose activities tend to negatively affect the property of other companies or households. Technological changes in industry reduce nuisances, but, at the same time, the negative impact of rapidly developing technical infrastructure of (road, rail and air) transport, as well as media transfer infrastructure, is increasing. These investments are often seen as public, quasi-public or shared goods, which results in the involvement of the state - at least in the legal protection of the conditions for the execution of the investments. This is usually demonstrated as interfering with the operating conditions of the property market and shaping the rules for pursuing compensation and setting compensation amounts. Any attempt to resolve a conflict over a nuisance requires determining who exercises control over all property involved. Once the ownership rights are confirmed, an injunction order is issued to stop the nuisance or the ownership rights are adjusted (transferred), 
which legalizes the nuisance and gives the injured property owner the right to seek compensation. In extreme situations, the ownership right is lost through expropriation or redemption. The intervention is usually discreet and results only in limiting the owner's power to exercise part of his ownership right (passive external impact) or in allowing the creator of the nuisance to use the property (active external impact). Only in the absence of the government's intervention (or court's intervention in customary law systems) would a solution be sought in the market relationship between both parties to the conflict. Nowadays, the law creates forced situations in which the state appears as the third party to the transaction and interferes with the property market by shaping the relationship between the injuring party and the injured property owner.

Restricting ownership is acceptable to a varying extent, which is why it is necessary to establish criteria to be taken into account both when issuing an injunction for a nuisance, as well as legalizing it in exchange for compensation. What becomes the key issue are the methodological principles for the valuation of damage in a forced situation for the owner of an affected property, when, for instance, its market value decreases as a result of a voluntary decision made by the owner of the neighboring (dominant) property. The asymmetry of the positions of the conflicted parties justifies the adoption of a research hypothesis stating that the damage valuation methodology should be based on the concept of fair value, which makes it possible to obtain full compensation for the suffered loss in assets. Within this context, the objective of this article has been formed, which is to present and critically evaluate, with reference to selected economic concepts, the current rules for determining compensation for immovable property affected by secondary nuisance created by companies, and to assess the usefulness of fair value in appraising property for that purpose. The considerations regarding the appraisal practice are discussed on the example of residential property of households located in the limited use areas (LUA) of airports.

\section{Literature overview}

State intervention in resolving conflicts in properties affected by indirect nuisance results in drawing up trilateral agreements which shape the specific conditions of market competition and have a wider impact on economic relations. This is broadly justified and reflected in economic literature, as well as in earlier philosophical deliberations concerning the origins of private ownership and justifying it. What is of greater importance for the issue considered is the justification of private ownership, which should be referenced to contemporary economic relations. Various ideas regarding the origins of ownership can be found in each monograph on the history of economic thought, as well as in specialist publications on this subject (Kategoria wtasności... 2015). The sources of the contemporary concept justifying private ownership date back to ancient philosophy and can also be found in the views of nineteenth-century economists. The issue of ownership seems to have made a journey of sorts - from philosophy and ethics to law and economics. Its philosophical foundations can be found in Aristotle's concept of equitable, or otherwise exchangeable, fairness (ARISTOTLE 2017, 1132 b 21 et seq.) related to the following transactions:

- free-market (voluntary) transactions, such as sales, donations, rental or lease, and other transactions, which, in case of nuisance, relate to purchasing ownership rights by enterprises,

- forced (involuntary) acts, such as profit theft, misappropriation of property space, unlawful use, land contamination, and others, which, in the case of nuisance, relate to the rules for determining compensation for damage caused by noise nuisance and to the property valuation methodology.

Even older, classic economic solutions that were doctrinally based on strong protection against this type of aggression towards ownership, proposed regulating the issue by entering into third party relationships, e.g. A. C. Pigou's concept of taxation presented in Economics of warfare (Economics of walfare (ŻYLICZ 2004, p. 68). This proposal refers to, and is justified by, the concepts of left-wing background justice by Rawls (RAWLS 1994, p. 32 et seq.), corresponds to Locke's proviso principle (LOCK 1992, p. 193) for joint property and, in certain cases, is even justified (although not accepted) in libertarian views regarding remedying violence with minimal interference from the state (NOZICK 1999, p. 5 and 186). In Poland, this assumption also corresponds to the full compensation principle (Act of Civil Code 1964, Article $361 \S 2$ ), which is to fulfill a compensatory function related to civil social liability. 
At present, property ownership is relatively protected. Initially, this was justified by social aspects and the criticism of market contracts has also been formulated from systemic positions, as it is argued that "contracts justify the conditions they themselves create" (SANDEL 2013, p. 194). However, what essentially continues to be applied is the efficiency justification stemming from the quite freely expanded and interpreted (FOX 2005, p. 2) Coase's theorem (COASE 1988). Efficiency solutions stand in sharp opposition to Locke's earlier libertarian concepts (LOCK 1992, Chapter 1, point 42). Those were based on the assumption of self-ownership (owning oneself) and the resulting prohibition to interfere with ownership rights, which were a result of one's own work. The basis for the socialization of the costs of external impacts was prepared by J.S. Mill. With reference to land resources, he highlighted the specific characteristics of land concerning its original nature and the economic consequences related to the lack of production costs: "No man made the land. It is the original heritage of the whole people" (MiLL 1965, chapter 2, item 6). In Europe, the perception of ownership is strongly related to Christian ethics, where, as a good of nature, land is owned by all (SEDLACZEK 2012, p. 167). At the same time, Christian ethics supports the individual ownership of goods, which was initially justified by the transfer of ownership (appropriation) of land by "combining [it] with work". (HOPPE 2011, p. 332 et seq.) - a view shared by libertarians. Hence, the ownership of private land in Christian ethics is subject to the universal destiny of goods (JOHN PAUL II 1991, Chapter 4, 31). This approach is different from liberal conceptions of ownership, which give man the right to make decisions regarding the ownership of goods indefinitely, freely and unobtrusively (BEŁCH 2007, p. 319).

In the efficiency approach, the conflict over nuisance is described as an imbalance between social and private costs, which is usually considered as one of the symptoms of market imperfection. It is assumed that, since they result from nuisance, external impacts become social costs (COASE 2013, p. 86). Coase's views were inspired and justified by rather simple observations of economic practice and analyses of court disputes, whose resolutions involved the State interference and shaped the operational conditions for markets of rare/finite goods ${ }^{1}$. Placing Coase's views at the heart of the considerations is justified both by the importance and controversial nature of the adopted methodological approach to analyzing and evaluating the conflict situation. Coase has resigned from the legal perspective which shaped the traditional understanding of private ownership protection and previously determined the framework for economists' deliberations. In its place, he introduced a freeof-legal-constraints analysis of ways to resolve disputes over nuisance, where the parties maintain equal positions, which required dismissing the classical concept of damage with clearly defined and opposing roles of the violator and the injured party. Coase abandoned the criterion of justice and adopted the efficiency perspective instead. This approach resembled the utilitarian criteria by Bentham, whose views are sometimes regarded as a turning point in contemporary economic thought (SKOUSEN 2012, p. 172). Coase set a similar turning point, the only difference being that his views regarded the social - not individual - utilitarianism perspective. He proposed that the conflict be analyzed from the perspective of an equal situation for both parties involved (the reciprocity of injury) by adopting a bilateral efficiency approach to external (social) costs.

By assuming that damage is mutual, Coase does not consider a priori that it necessary for the state to intervene, but rather seeks justification for avoiding the intervention. However, he demonstrates that only when transaction costs are low (and several other conditions are met) is it more effective, and therefore better, to let the costs of external impacts be settled through market negotiations. For high transaction costs, the court (and in civil law systems, a provision of the law and/or court interpretation) should take into account the interests of the party that suffers greater harm in a given conflict. Coase introduces the principle of exclusion or limitation of the liability of the owner of a dominant property (a perpetrator in the classical sense) in order to avoid greater loss in the social sense. Abandoning the principles of justice, which had been in force until then and had strong

\footnotetext{
1 Coase's first publication concerned the rules for regulating radio frequencies by the state. He proposed that decision-making on allocating ownership rights in this area be shifted from governmental (administrative) authorities to the market. The analysis criterion was to ensure the highest efficiency of use, understood as the maximization of revenue - the value of production (COASE, 2013, p. 26 et seq.). See contemporary references to this issue, e.g. a failed auction in New Zealand under W. Vickrey's rules (a Nobel Prize laureate for significant advances in the use of game theory in tenders) or a successful tender in the UK, according to the principle "Nobody is in a position to lie. Talk is cheap, ... ". (HARFORD 2011, pp. 257 and 252 and SMITH 2013, p. 130).
} 
institutional grounds, and excluding, or at least reducing, the liability of the perpetrator of damage in favor of efficiency at the social level, were met with harsh criticism, at first mainly from law theory circles (STELMACH, BROZEK, ZAŁUSKI 2007, p. 40). Further multifaceted analysis of Coase's works shaped the meaning of his concept in literature (compare COOTER, 1982). This was reflected in giving his publication the status of theorem by Stigler in 1966. Despite the criticism, Coase's position as the forerunner of the new efficiency approach to resolving conflicts over nuisance is indisputable. Regardless of whether the applied justification criteria are Coase's social or Bentham's utilitarian ones, interfering with property ownership rights is always associated with the restriction of human liberty. In this context, a justification for the property market as a solution that is fair by definition is presented by Nozick (NOzICK 1999). Based on his views, one may conclude that the legitimization of nuisance according to Coase's views invalidates some property rights and imposes the way of settling the damage by an uncertain court-imposed obligation.

Domestic literature on property damage appraisal essentially lacks economic publications on the application of fair value for the purpose of calculating compensations. Extensive philosophical and legal literature (Sprawiedliwość ... 2009; Doktryny polityczne i prawne 2002; RADWAŃSKI, OLEJNICZAK 2010) creates merely a framework for the methodology that needs to be filled in with content (image) to enable its practical use in the economy. There is also no domestic economic literature that would comprehensively discuss the methodology of property appraisal for the purpose of calculating compensation in conflict situations caused by indirect nuisance. For example, publications related to damage done to property located in the LUAs of airports and the decrease in the value of property located around airports focus on the issues of market analysis and the application of tools, mainly multiple regression, on the assumption that a conflict can be resolved based on the market value (BIEN 2011; HeRMANN, KOSMOWSKI 2007; KRAJEWSKA , SZOPIŃSKA 2014; TROJANEK, HUDEREK-GLAPSKA 2017). This is due to the legal institutionalization of property appraisal principles and the absence of the concept of "fair value" from legal regulations. Since it is obligatory to perform property appraisal based on market value or replacement value (Act Of 1997, Article 150), the same approach is adopted for research. Fair value for settlement purposes ${ }^{2}$, defined in the European and international valuation standards (IVS 2011, p. 86 and EVS 2016, p. 121), cannot be applied in practice and is also omitted in scientific studies.

\section{Methodological framework for approaching fair value}

Research methodology has been clarified using the approach by R.A. Posner, who presented a concept of studying a legal system with the premise of discovering or designing economic principles by which the system operates or should operate (POSNER 1977). These studies concerned the common law system with the dominant position of law-making judges (judge-made legal system) who decide, on a practical level, about the implementation of the principle of fairness or the adoption of the efficiency criterion. That is why detailed issues regarding the methodology required further analysis and adaptation to the Polish system of codified law. Only Posner's general methodological approach is used in this article, so the fact that Poland has a different legal system is of no significance. One must only remember that, in the system of codified law, it is legal regulations and courts' lawmaking (GOLECKI 2011, p. 47) that influence the shaping of economic relations. Posner's distinction between normative and positive economic analysis of the law is important here. The former is used to explain and evaluate the effects of existing legal regulations and to examine the economic justifications of the applied interpretation of the law (explaining the world as it is). In turn, normative analyses lead to forming recommendations on the required directions of changes in the law, whose task would be to fulfill specific objectives aimed at improving the world (trying to change the world to make it better). However, all this is considered in the context of the efficiency criteria (POSNER 1979, p. 285 et seq.). The

\footnotetext{
${ }^{2}$ Fair value is an estimated price at which a component of assets or liabilities could be exchanged between strictly defined, well-informed and firmly committed parties to a transaction, and which reflects the interests of each party (IVS 2011, p. 86). The criterion for distinguishing this estimation basis is subjective. It is a price that would be reasonably agreed on between two individual parties to the asset component sales transaction. According to IVS and EVS, fair value is only the basis for property valuation and cannot be used as a basis for the valuation of damage.
} 
division into normative and positive assessments allows for distinguishing two subjectively different types of analyses which may apply to the following:

- regulated phenomena - usually in the positive approach, e.g. changes in the functioning of the property market related to sales prices and costs after LUA has been established,

- regulating behavior, e.g. a legal system which restricts property use and compensation amounts in various ways.

These are not autonomous research areas and, in practice, analyses results will overlap and complement each another. Thus, there are two (positive or normative) approaches to examining the problem of compensation claims related to nuisance, which can be applied in two areas of research concerning regulating and regulated behavior. In the case of conflicts over noise nuisance in the LUAs of airports, one can examine the relationships and reactions of entities regulated by the legal system, i.e. enterprises that produce nuisance and households that suffer the impact, or examine the structure of the legal system which creates the operating conditions of these entities. Table 1 presents the classification of research areas concerning damage done to residential property in the LUAs of airports.

Table 1

The classification of research areas concerning damage done to residential properties in the LUAs of airports

\begin{tabular}{|c|c|c|c|}
\hline \multirow{2}{*}{ No. } & \multirow{2}{*}{$\begin{array}{l}\text { Type of } \\
\text { analysis }\end{array}$} & \multicolumn{2}{|r|}{ Study area } \\
\hline & & Behavior of regulated entities & Regulating system structure \\
\hline 1 & Positive & $\begin{array}{l}\text { Analysis of changes in property } \\
\text { market prices in reaction to news } \\
\text { about the expansion of the airport. } \\
\text { Analysis of the market value of } \\
\text { compensations negotiated voluntarily } \\
\text { in the LUAs of airports. }\end{array}$ & $\begin{array}{l}\text { Comparison of the rules for determining the value } \\
\text { of damage caused by different types of nuisance } \\
\text { (e.g. indirect or direct) and for different types of } \\
\text { property. Analysis of methodological relationships } \\
\text { between damage to property and damage to } \\
\text { movable property and enterprises. }\end{array}$ \\
\hline 2 & Normative & $\begin{array}{l}\text { Assessment of transaction costs borne } \\
\text { by households in the absence of a legal } \\
\text { regulations determining the method of } \\
\text { calculating compensation }\end{array}$ & $\begin{array}{l}\text { Assessment of the effects of changes in the rules } \\
\text { for calculating compensation from LUAs }\end{array}$ \\
\hline
\end{tabular}

Source: own study.

The publication focuses on examining the structure of the regulatory system by using a positive (descriptive) analysis, where the application of a descriptive model (also called functional, see HAJDUK 1972,78 et seq.) is primarily intended to explain the role of fair value as a basis for property appraisal for the purpose of calculating the cost of damage. It is assumed that such a basis for damage valuation will first be adopted and clarified ${ }^{3}$ in legal regulations. The results of the descriptive study can be used to design improved methods of solving conflicts over nuisance at the level of institutional order. The normative solution may include fair value of compensation, intended to protect the property owners against the loss of property equity due to nuisance.

Fair value changes the perspective of determining the value of damage and, therefore, belongs to the normative categories of the regulatory system structure study area. The same reservation concerns fair value as a basis for property valuation. At the same time, fair value can also be examined in the context of the market value of ownership rights, determined in voluntary agreements concluded by and between the nuisance-producing enterprises and property owners. This type of studies refers to the behavior of regulated entities and may be positive (descriptive). All in all, it becomes apparent that the studies of fair value are complex, which results from the duality of both the research area and the methodological approach.

\footnotetext{
${ }^{3}$ It concerns the following: the subject matter and scope of valuation, important dates to determine the condition of property and market conditions accepted for valuation, recommendation of selected valuation methods or their exclusion and rules for conducting market analyses for a specific purpose related to searching for the difference in value, whereby it is necessary to demonstrate the cause-and-effect relationship. This requires specific structuring of the valuation process, particularly in terms of adopting an appropriate model for market analysis (see HoYLE R.H. (ed.) 1995, p. 289 and CARVALHO, CHIMA 2014, pp. 6-12).
} 
The undertaken attempt to adopt a comprehensive and integrated approach to legal and economic issues, valuation theory and the methodology of property appraisal for compensation purposes also requires reference to the practice of real property appraisers. This methodology is broadly understood and, as stated by Kotarbiński, it is a "systematically used method" (KOTARBIŃSKI 1986, p. 232), including such selection and arrangement of indicated activities as to attain the set objectives. The methodology of property appraisal should be subject to normative legal principles of determining the value of damage, which should introduce fair value as a basis for valuation. In order to sum up and organize the theoretical framework of this publication, it should be pointed out that the research was limited in the following areas:

- institutional area, due to the adoption of the perspective of commutative justice, referred to part of the basic structure of the society - creating a comprehensive background for justice, with an additional assumption of the rationality of persons who shape institutions (RAWLS 1994, 362 et seq.),

- methodological and subjective area, addressing the issue of fair value, primarily from the positive perspective, the perspective of a descriptive model which clarifies the behavior of regulated entities, as well as the structure and functioning of the regulatory system,

- objective area, addressing the issue of private property operating in competitive, active and relatively liquid markets, where there exist opportunities and the costs of exclusion from usage are low, and where the issuer of a nuisance is the injuring company and negative impacts affect the residential property of a household,

- methodological area, considering primarily situations where the adjustment of ownership rights to an affected property takes place under the conditions of a forced trilateral transaction with direct third party interference - in the case of the Polish legal system, these will be legal regulations and their judicial interpretations.

An assumption has been made to conduct an integrated analysis of the methodology, which would allow for introducing fair value into economic practice while maintaining the distinct character and primacy of the principles for determining property value, which always requires methodological concretization (KUCHARSKA-STASIAK 2012, p. 9). In particular, this concerns the purpose of appraisal associated with the estimation of the cost of damage to property located in LUAs. The omitted areas designate issues for further research.

\section{Efficiency and justice in conflicts over nuisance}

The creation of nuisance by enterprises always leads to conflicts. Only when property ownership rights are fully and absolutely protected, can any claims for the termination of a nuisance be effective. An alternative for the perpetrator (for example, an airport company) would then be to either acquire ownership rights to the private property on the basis of a bilateral free-market contract or to relocate. In the absence of state intervention, bilateral transactions (between entities: A - residential property owner and B - airport) are concluded via the market and valuation is based on the market value, determined as a result of the convergence of two investment values from the buyer's and seller's valuations ( SAYS et al. 2006, p. 16).

\section{A MarketValue $\quad$ B}

Fig. 1. Relations between parties to a bilateral agreement. Source: own study.

The market is a natural, unique and fair exchange environment which could lead to a positive game result (AYAU 2010) and foster the creation of wealth, which also relates to conflicts over nuisance. The arrows in Figure 1 represent mutual interactions in negotiations between equivalent entities A and B (the same letter size), but there is information asymmetry (thicker arrow) indicating that the airport (B) has a greater impact on the residential property owner (A). This, however, is no obstacle to implementing fairness based on the benefits of a market exchange in a "forced" situation where there are no alternative solutions and the negotiation of contracts takes place only between two specific parties (SMITH 2013, p. 93). The condition is there being no third party interference. 


\section{$\$$ sciendo}

An example of absolute protection of ownership and preference for bilateral relations could be the principle of primacy, protecting the existing way of property usage from unfavorable changes in the neighborhood. Another most commonly used criterion is the assessment of the impacts of changes at the social level, which opens the way to the exclusion of the absoluteness of claims for the injunction of a nuisance. In the latter case, a nuisance created by the (dominant) property belonging to an enterprise becomes legalized in a way, as the owner of the neighboring (affected) property may not object to the nuisance (RAKOCZY 2010, p. 166), but may only seek compensation. In a classic neighbor dispute over a noise nuisance between corporate real estate (a newly built medical practice and a pastry shop, which had been run by its former owner without any problems for 60 years), the scope of protection of the entities' ownership rights depends on the answer to the following question: is it more profitable to resign from pastries or doctor's services? (COASE 2013, pp. 95-97). Legalization of noise from a LUA of an airport is justified by making a comparison between the profitability of canceling all flights or reducing their number while respecting domestic peace and protection of the capital of households invested in flats. In this case, social efficiency (profitability) criteria override the natural criteria of fairness based on the principles of the allocation of property rights through unrestricted, voluntary market agreements.

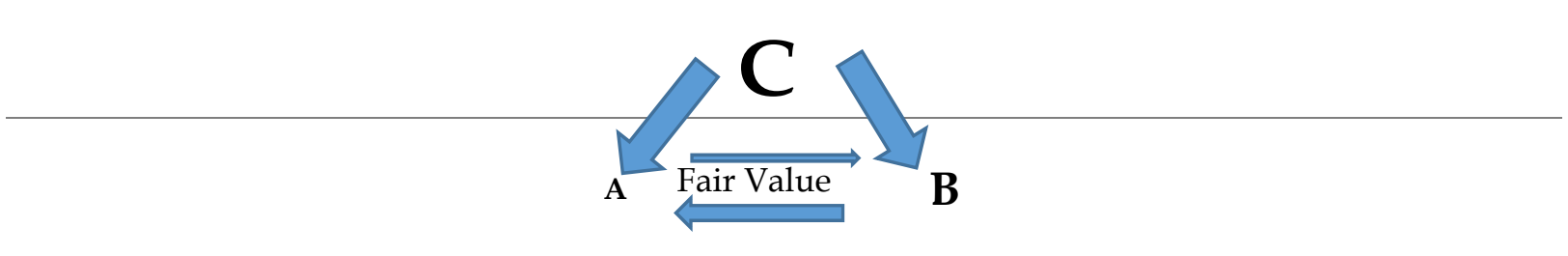

Fig. 2. Relations between parties in a trilateral agreement Source: own study.

The arrows in Figure 2 show mutual interactions in negotiations between the non-equivalent entities A and B (different letter sizes) and the dominant entity C (the state - acting as a regulator and not entering into direct relations), with maintained information asymmetry between $\mathrm{A}$ and $\mathrm{B}$ and concentration of both parties to the dispute on relations with the dominant side $C$ (thicker arrows). There is no negotiation interaction A: C and B: C (no arrows directed this way).

Property-related disputes over nuisance are currently dominated by social utilitarianism and efficiency criteria with the principle of comparing the market costs of bilateral transactions (market mechanism cost) with the alternative of dispute settlement costs in trilateral transactions involving the State. The external impacts, created as a result of a nuisance, are assessed on the assumption of reciprocity and equivalence of damage, where the roles of the perpetrator and injured party are blurred. Effective assessment of damage becomes a basis for creating solutions in the system of customary law that not only accept interference by the State, but also give it a strong position. Disputes are resolved with the participation of a third party to the conflict, but the common law system incorporates a rule that the judges' decisions or legal regulations should imitate the market and the final decision should be similar to the situation simulated in Figure 1. The advantage of the solution involving third party participation is lower transaction costs. The key assumption is that the lack of absolute property ownership protection is aimed to improve prosperity by reducing transaction costs due to the exclusion of relatively high market mechanism costs. Instead, the third party - in this case the state - grants ownership to entities that value it the most, with costs lower than those generated in the free market.

The market mechanism is thus replaced by a court decision or a legal regulation which entails problems related to the following:

- valuation criteria and method; alternative costs (market mechanism costs or social costs) are higher (BUCHANAN 1969, p. 14 et seq.),

- rules for determining the value of damage that substitute market rules, as proper market data (e.g. transaction prices) may not be available, or the law may not provide for an appropriate valuation basis.

The most essential assumption is that damage exists only in the market efficiency perspective. This means there will be no possibility of proving the existence of damage in a situation when a negative nuisance factor (reason) does not cause a decrease in market prices (result). The lack of such a response may result from too low information efficiency of the market or the occurrence of interfering 
factors, e.g. an increase in demand caused by good economic conditions or an improvement in the availability and reduction of credit costs. It could be argued then that the legal system lacks its own principal justification (cf. KUBISZ 2017, p. 140). The concept of the reciprocity of injury means that there are no objective or unequivocal criteria for prohibiting a nuisance. They are derived subjectively from the criteria of social efficiency, which is used to assess a greater benefit (or to prevent a greater loss) for one of the parties to the conflict. Introducing such a solution into the legal system, including a system of customary law, affects the market structure and the level of prices, as it leads to changes in the distribution of income and the method of the distribution of goods (BLOCK 1995, p. 62 et seq.), and, by analogy to other state interventions, it affects the informational efficiency of the market (Winfree, Mckluskey 2007, p. 322). In the codified law system, legal regulations become institutional market regulations that directly influence investment decisions made by the parties to the conflict. Any appraisal of value in a market functioning in these conditions will be "contaminated" by prior state interference, which has changed the conditions of market competition, the market structure and the level of prices. This determines the futility of the market value as a basis for appraising property for the purpose of compensation, as the market value includes the impacts of the intervention. This is because the market acts according to terms and conditions previously shaped by the law. The negotiation position of the parties to the conflict is established earlier by legal regulations. Instead of fulfilling the condition of imitating freedom and competitiveness, there is imitation of a market operating under the influence of factors generated by the intervention. The participants of this market (especially buyers) will take preventive measures to protect themselves from probable losses, following the rule which says that losses count more than gains (NOVEMSKY, KAHNEMAN 2005, p. 119 et seq. and KAHNEMAN 2012, p. 376).

When using the market value as a valuation basis, parties concluding settlement agreements and courts issuing judgments based on expert opinions may not imitate the market, understood as the maintenance of classic bilaterally favorable relations. They can only imitate the market that anticipates the decisions of judges in the common law system or anticipates the effects of legal regulations in the codified law system. In the absence of fair value, there occurs a preventive change in the hierarchy in the functioning economic model. In a market process based on the benefits from bilateral relations, ownership does not depend on efficiency, but determines it. In a free and competitive market, property is purchased by an entity that values this good the most. This requires meeting the condition of the best (optimal) use, which will allow the highest market price to be paid. In the market of real property affected by nuisance, the relationship is currently reversed, as granting the ownership of property rights is determined by the utilitarian efficiency criterion applied to the market value.

For bilateral transactions done through the market, valuation is based on the market value. In the event of the legalization of nuisance, transactions are trilateral, as the two parties to the contract are joined by a third one - the state. In such situations, valuation should be based on fair value, which, even though the positions of the two sides of the conflict are not equal, should, in practice, make it possible to obtain full compensation for the loss in assets. This is to be guaranteed by the institutional operation of the third party - the state - at costs lower than those generated by the market mechanism. On the whole, under the State's supervision and with its consent, there occurs a significant change in the situation between the two parties to the transaction. Trust, on which concluding market contracts is based, becomes replaced, at best, by the principle of reciprocity. This justifies the use of fair value as the basis for valuation, since only then is it possible to properly balance the interests of the conflicted parties. In Poland, however, no fairness criteria have been determined which could serve as a basis to assess currently applied solutions and to create changes to introduce fair value as the basis for valuation property for the purpose of calculating compensation. The normative character of fair value points to expectations that it will bring about effects in terms of distributive justice. Such establishment of fair value leads to an overarching institutional development of the operational conditions of the property market by introducing a third party into bilateral market agreements which acts as an arbitrator. Fair value understood in this way is a market institution that fulfills its role through provisions of the law, which politically determine social objectives related to the implementation of distributional justice, shaping the organizational structure of the market and affecting investors' motivation. In Poland, introducing this category may be justified by the model of social market economy and the introduced constitutional principle of striving for social justice. The issue of fair value affecting the distribution of property ownership rights in the market is not relevant 
for shaping this category in terms of valuation practice and its professional standardization. It is a domain of jurisprudence, taking into account economic law analysis.

What is the right perspective for the professional standardization of property appraisal methodology is the recognition of fair value as a concept of the implementation of equitable justice. On the basis of the specialist knowledge of experts, discretional solutions can be developed at the level of professional standards, which, through the principles of good practice, become an institution that affects the ways of resolving disputes by developing a separate valuation basis for selected valuation objectives related to forced transactions. As a result, fair value is used whenever property ownership rights are traded under non-voluntary conditions. This would also apply to calculating the value of damage caused by a nuisance.

\section{Summary and conclusions}

In order to resolve the civil law dispute regarding the violation of property ownership rights, it is necessary to develop and adopt a specific theoretical concept and to institutionalize it at the level of the basic structure of society which regulates the principles of cooperation, as this is a decisive factor in the distribution of income (RAWLS 1994, p. 87). By expanding its business beyond the controlled space of its own property ownership rights, an airport negatively affects the utility and value of neighboring properties. A dispute over nuisance is resolved by means of a forced trilateral transaction, concluded with the third party $(\mathrm{C})$ whose position is strong. It determines ex ante the terms and conditions of the settlement or the criteria that are taken into account by the court before it passes its judgement on the matter. Moreover, it secondarily influences the functioning of market competition. The correct calculation of compensation in a trilateral agreement requires developing a comprehensive methodology, a key element of which is the normative category of (the type) of value taken as the basis for the valuation of damage, which is transferred secondarily to the property appraisal methodology. The legal regulations in Poland provide for using the market value or replacement value (for specialized non-marketed property) for this purpose. There are no legal regulations indicating fair value as the basis for valuation and only changes in the law can make its future application possible. In Poland, the issue of using fair value in the valuation of property ownership rights of enterprises requires taking into account a rather unusual situation where, in the codified law system, there are no relevant civil law regulations or specific legislation, and the regulations of professional standards are still in their initial phase.

This leads to an increase in the importance of the discretionary judicial power, which uses the specialist knowledge of experts for methodological solutions. Critical assessment of the usefulness of market value as a basis for property valuation for compensation purposes is of key importance. In Poland, market value is a well-established and strongly institutionalized category. Currently, all market disputes are settled on the basis of market value (Act of 1997, Article 150), which results in rare cases of concluding voluntary agreements at low transaction costs and numerous costly litigations. The hypothesis of system-impaired resolution of conflicts over indirect nuisance affecting property in the absence of adopting fair value as a basis for the valuation of damage has been positively verified. Methodological solutions regarding fair value set forth in European and international standards can be adapted to national standards, but first, changes must be made in the legal regulations in terms of the methodology of assessing damage caused by indirect nuisance. This requires further research into how to use economic law analysis in order to design a comprehensive methodology for assessing the value of damage to property, and the professional standardization of fair value can only be an element of such a solution, following the confirmation of its legality. Coase's theorem has fundamental theoretical significance and serves as a basis for creating methodological assumptions for the calculation of compensation and to further establish principles of property valuation, which constitute an element of the necessary operationalization of the theoretical concept.

For practical application, the following methodological aspects will be relevant and will also require further research:

- the parties to a dispute over nuisance expect solutions that eliminate uncertainty instead of (socially) effective solutions,

- past experiences show that impacts result in protection only for the wealthy in disputes resolved with the participation of the state and omission of the market (STELMACH, BROZEK, ZAŁUSKI 2007, p. 79), 
- in practice, courts may find it difficult to be regularly guided in their rulings by criterion based on the search for efficiency and to allocate property ownership rights according to changes in the operational conditions of the market,

- judicial solutions based on the concept of fairness or similar legal regulations in the system of codified law do not always correspond to efficiency criteria as presented by Coase.

\section{Literature}

ARYSTOTELES, 2017, Etyka Nikomachejska (Nicomachean Ethics), PWN, Warszawa,

AYAu M.F., 2010, Paradoks wymiany Not a Zero-Sum Game: The Paradox of Exchange, Fijorr Publishing, Warszawa.

BЕєCH K.,2007 Katolicka nauka spoteczna. Podręcznik dla studentów teologii i nauk spotecznych (Catholic Social Teaching. Handbook for Students of Theology and Social Sciences), Wydawnictwo Jedność, Kielce,

BIEŃ G., 2011, Hatas lotniczy a wartość nieruchomości zabudowanych domami mieszkalnymi jednorodzinnymi w Poznaniu $i$ Luboniu (Air Noise and the Value of Residential Real Estate, Single-family Houses in Poznań and Luboń) Biuletyn SRMWW (SRMWW Bulletin) No. 4/2011, Poznań,

BUCHANAN J.M., 1969, Cost and Choise, Chicago,

Bum A, CROSBY N. 1995, Property Investment Appraisal, $2^{\text {nd }}$ ed., Routledge, London - New York,

CARvalho De J., Felix O. ChImA F.O, 2014, Applications of Structural Equation Modeling in Social Sciences Research, American International Journal of Contemporary Research Vol. 4 No. 1; January, http://www.aijcrnet.com/journals/Vol_4_No_1_January_2014/2.pdf, dostęp 11.11.2017,

COASE R., 1988, The Firm, the Market and the Law, University of Chicago Press, Chicago,

COASE R., 2013, Firma, rynek i prawo (The Firm, the Market and the Law) Wolters Kluwer, Warszawa,

COOTER R., 1982, The Cost of Coase, Jurnal of Legal Studies, vol. XI (January), Available at: http:// scholarship.law.berkeley.edu/facpubs/84, 25.04.2017,

Doktryny polityczne i prawne u progu XXI wieku. Wybrane problemy badawcze (Political and Legal Doctrines at the Beginning of the 21st Century. Selected Research Problems)2002, red. M. Maciejewski i M. Marszała, Wrocław.

Europejskie Standardy Wyceny 2016 (European Valuation Standards 2016), (EVS 2016) 2017, PFSRM/PFVA, Warszawa,

Fox G., 2004, The Real Coase Theorems, Department of Agricultural Economics and Business, University of Guelph.

GOŁECKI M.J., 2011, Między pewwościa a efektywnościa. Marginalizm instytucjonalny wobec prawotwórczego stosowania prawa (Between Certainty and Efficiency. Institutional Marginalism in the Context of the Law-making Application of Law, Lex a Wolters Kluwer Business, Warszawa,

HajDuk Z., 1972, Pojęcie i funkcja modelu (The Concept and Function of the Model) "Roczniki Filozoficzne", T. 20, Z. 3.

HARFORD T., 2011, Sekrety ekonomii (The Undercover Economist), Wydawnictwo Literackie, Warszawa.,

HERMAN B., 2014, Problematyka oceny zmiany wartości nieruchomośsi w zwiazku z tworzeniem obszarów ograniczonego ubytkowania wokót lotnisk (Issues of Assessment of Real Esate Value Changes in Connection with the Creation of Limited Use Areas Around Airports), Biuletyn SRMWW, No. 3/2014, Available at: https://srmww.pl/images/biuletyny/2014/3_2014/34-49.pdf, 15.06.2017,

HERMANN B., KOSMOWSKI M., 2007. Wartość nieruchomości obarczonych wada niekorzystnego sasiedztwa (The Value of Real Estate with a Disadvantage of an Unfavorable Neighborhood), Biuletyn SRMWW, No. 1/15, Poznań,

Hoppe H.H., 2011, Ekonomia i etyka własności prywatnej. Studia z zakresu ekonomii politycznej i filozofii (The Economics and Ethics of Private Property. Studies in Political Economy and Philosophy) 2nd Edition, Fijorr Publishing Company, Warszawa,

Hoyle R.H. (ed.), 1995, Structural Equation Modeling. Concepts, Issues and Application, Sage, Thousand Oaks London - New Dehli,

International Valuation Standards 2011 (IVS2011), Ninth Edition, 2011, International Valuation Standards Committee, London,

JAN PAWEE II, 1991, Encyclica. Centesimus annus, Available at: http:/ /www.nonpossumus.pl/encykliki/ Jan_Pawel_II/centesimus_annus/IV.php_17.03.2017,

KAHNEMAN D., 2012, Pułapki myślenia, o myśleniu szybkim $i$ wolnym (Thinking Traps, on Fast and Slow Thinking), Media Rodzina, Poznań,

Kategoria wtasności w ujęciu wybranych kierunków myśli ekonomicznej (Property Category in Terms of Selected Directions of Economic Though)t, 2015, red. nauk. U. ZAGÓRA - JONSZTA, Wydawnictwo WNT, Warszawa,

KOTARBIŃSKI T., 1986, Elementy teorii poznania, logiki formalnej i metodologii nauk (Elements of the Theory of Cognition, Formal Logic and Methodology of Sciences) Warszawa, PWN,

KRAJEWSKA M., SzOPINSKa K. , 2014), Hatas środowiskowy jako element oceny lokalizacji nieruchomości mieszkaniowych, (Environmental Noise as an Element of the Assessment of Residential Real Estate Location), Biuletyn SRMWW, No. 3/2014, Poznań,

KubISZ J., 2017, Teoria Ronalda Coase'a a własność i odpowiedzialność za szkodę (Ronald Coase's Theory and Ownership and Responsibility for Damage), Available at: http://www.bibliotekacyfrowa.pl/Content/34394/0009.pdf, 24.04.2017, 
KUCHARSKA-STASIAK E, 2012, Wycena bez wartości - przyczyny i skutki (Valuation with No Value - Causes and Effects), Studia i Materiały (Journal of the Polish Real Estate Scientific Society) , Vol. 20, Issue 2, TNN, Olsztyn,

LANCASTER, K., 1966, A New Approach to Consumer Theory. Journal of Political Economy, Vol. 74, No. 2 , Apr., Available at: http://www.jstor.org/stable/1828835, 5.07.2016,

LOCKE J., 1992, Dwa Traktaty o rzadzie/ Two Treatises of Government, przeł. Z. Rau, Warszawa: Wydawnictwo Naukowe PWN,

Malington A.F., 1988, An Introduction to Property Valuation, London,

Międzynarodowe Standardy Wyceny 2011, wydanie polskie (International Valuation Standards 2011) Polish edition, 2012, PFSRM/PFVA, Warszawa,

MiLl J.S., 1965, Zasady ekonomii politycznej (Principles of Political Economy) PWN, Warszawa,

NOVEMSKy N., KAHNEMAN D., 2005, The Boundaries of Loss Aversion, Journal of Marketing Research 42,

NozicK R., 1999, Anarchia, państwo i utopia (Anarchy, State, and Utopia) Wydawnictwo Aletheia, Warszawa,

POSNER R.A., 1977, Economic Analysis of Law, 2nd edition (Little, Brown and Company, Boston),

Posner R.A., 1979, Some Uses and Abuses of Economics in Law, The University of Chicago Law Review, 1979, No. 2, Vol. 46,

RADWAŃSKI Z., OlEJNICZAK A., 2010, Zobowiązania-część ogólna (Commitments - General Part) Warszawa.

RAWLS J., 1994, Teoria sprawiedliwości (Theory of Justice), przeł. M. Panufnik, J. Pasek, A. Romaniuk, Wydawnictwo Naukowe PWN, Warszawa,

SANDEL M.J.,2013, Sprawiedliwość. Jak postępować stusznie? (Justice. What's the Right Thing to Do?) przeł. O. Siara, Kurhaus Publishing Kurhaus Media sp. z o.o. sp. k., Warszawa,

SAYCE S. et. al., 2006, Property Appraisal: From Value to Worth, Blackwell Publishing, Oxford,

SEDlaczeK T., 2012, Ekonomia dobra i zła (Economics of Good and Evil) przeł. D. Bakalarz, Wydawnictwo Studio Emka, Warszawa,

SKOUSEN M., 2012, Narodziny wspótczesnej ekonomii. Żywoty i idee wielkich myślicieli (The Making of Modern Economics) Fijorr Publishing Company, Warszawa,

STELMACH J., BROŻEK B., ZAŁUSKI W., 2007, Dziesięć wykładów o ekonomii prawa (Ten Lectures on the Law Economy) Warszawa,

SMITH W.L.,2013, Racjonalność w ekonomii (Rationality in Economics. Constructivist and Ecological Forms) Oficyna Wolters Kluwer Business, Warszawa,

Sprawiedliwość - idee a rzeczywistość (Justice - Edeas and Reality) 2009, red. P. Jaroszyński i in., Fundacja “Lubelska Szkoła Filozofii Chrześcijańskiej”, Lublin,

TROJANEK R, HUDEREK-GLAPSKA S. (2017), Wptyw ustanowienia obszaru ograniczonego użytkowania dla Portu Lotniczego im. Fryderyka Chopina w Warszawie na ceny nieruchomości mieszkaniowych (Impact of Establishing a Limited Use Area for the Warsaw Chopin Airport on Housing Prices), w: red. M. Trojanek, M. Rącka, Nieruchomość w przestrzeni 3 (Real Estate in Space 3), Wydawnictwo PWSZ w Kaliszu, Kalisz,

Ustawa z dnia 23 kwietnia 1964 r. Kodeks cywilny (Act of 23 April 1964 Civil Code) Dz. U. z 1971 r. Nr 16, poz. 93 ze zm. (Journal of Laws of 1971, No. 16, item 93, as amended),

Ustawa z dnia 21 sierpnia 1997 r. o gospodarce nieruchomościam (Act of 21 August 1997 on real estate management) tekst jednolity Dz. U. poz. 2147, z 14.12.2016 r. ze zm. (consolidated text Journal of Law, item 2147 of 14.12.2016, as amended),

Winfree J.A., MCKLUSKey J.J., 2007, Takings of Development Rights with Asymetric Infomation and an Endogeneus Probability of an Externality. Journal of Housing Economics 16, Vol. 33, Available at:, doi:10.1016/j.jhe.2007.08.003, 27.07.2017. 